\title{
Sharp injuries: a cross-sectional study among health care workers in a provincial teaching hospital in China
}

\author{
Zhuo Cui ${ }^{1}$, Jingrui Zhu' ${ }^{1}$ Xiangjun Zhang ${ }^{1}$, Bairu Wang ${ }^{1}$ and Xiaojun $\mathrm{Li}^{2^{*}}$
}

\begin{abstract}
Background: The objectives of this study are to investigate the incidence and reporting behavior of sharp injuries among healthcare workers (HCWs) and identify the risk factors associated with these injuries.

Methods: A cross-sectional survey was conducted in February 2017 in a provincial teaching hospital in China. Data were collected from 901 HCWs using a self-administered questionnaire which included demographic information, experience, and reporting behavior of sharp injuries. Stepwise logistical regression was used to analyze the risk factors.

Results: HCWs (248 [27.5\%]) had sustained a sharp injury in the previous year. Factors including seniority, job category, title, education, department, and training programs were associated with the occurrence of sharp injuries. According to the stepwise logistical regression, seniority, and training programs were the risk factors associated with the occurrence of sharp injuries. Of 248 sharp injuries, 130 HCWs were exposed to blood. Only 44 (33.9\%) HCWs reported their injuries to the concerned body. The main reasons for not reporting the sharp injuries were as follows: perception that the extent of the injury was light (30.2\%), having antibodies (27.9\%), and unaware of injury (16.3\%).

Conclusions: Sharp injuries in the studied hospital were common and were likely to be underreported. Therefore, an effective reporting system and sufficient education on occupational safety should be implemented by the relevant institutions. Moreover, it is important to take effective measures to manage sharp injuries in HCWs and provide guidance for their prevention.
\end{abstract}

Keywords: Blood-borne diseases, Healthcare workers, Incidence, Sharp injuries, Underreporting

\section{Background}

Sharp injuries are defined as accidental skin penetrating stab wounds caused by hollow-bore needles such as hypodermic needles, blood-bore needles, catheter stylets, and needles used to connect parts of a delivery system. Sharp injuries are the most common occupational injuries among healthcare workers (HCWs). HCWs are especially prone to sharp injuries during their work periods and infection after exposure [1]. The World Health Organization estimates that 1 in $10 \mathrm{HCWs}$ worldwide sustain a sharp injury each year [2]. Sharp instruments contaminated by blood-borne pathogens are the main

\footnotetext{
* Correspondence: lixiaojun19701219@163.com

${ }^{2}$ Department of Medical Affairs, First Affiliated Hospital of Bengbu Medical College, 287 Changhuai Road, Bengbu 233004, People's Republic of China Full list of author information is available at the end of the article
}

factors in occupational exposure to blood-borne diseases among HCWs. They are at risk of infection due to blood-borne viruses including hepatitis B virus (HBV), hepatitis $\mathrm{C}$ virus (HCV), and human immunodeficiency virus (HIV) [3, 4]. Globally, approximately 66,000 HBV, $16,000 \mathrm{HCV}$, and $1000 \mathrm{HIV}$ infections occurred in HCWs due to sharp injuries in 2000 [5]. The estimated annual costs for tests and the treatment of sharp injuries vary from $\$ 6.1$ million in France to $\$ 118-591$ million in the USA [6].

Reporting of sharp injuries is important for treatment and prevention. For the injured person, injury reporting prompts evaluation for post-exposure prophylaxis, allows early detection of seroconversion and helps to decrease anxiety. Furthermore, injury reporting allows identification of hazardous devices or procedures and so 
diminishes the risk of future injuries [7]. The underreporting of sharp injuries by employees has been documented in various studies. The magnitude of underreporting is 22 to $99 \%$ [8]. Due to the low reporting rate, post-exposure prophylactic management is not possible in many cases.

Although studies have been conducted on sharp injuries in developing countries $[9,10]$, there are few available data on sharp injuries and reporting behavior in China. To understand the risk factors for sharp injuries and determine the corresponding preventive countermeasures, we carried out a cross-sectional investigation at a provincial teaching hospital in Anhui province, China.

\section{Methods}

The study was carried out in a tertiary affiliated teaching hospital of medical college in Anhui province, China, in February 2017. We investigated $901 \mathrm{HCW}$ s from January to December 2016, using a self-administered questionnaire. This hospital is a provincial teaching hospital which has 1050 beds and employs approximately 1200 HCWs. The questionnaire was based on sharp injuries in China and other countries [11-13]. A pre-survey was conducted in the surgery department on December 20 2016. We distributed 36 questionnaires and 34 were available for analysis, resulting in an overall response rate of $94.4 \%$. According to the pre-survey and existing problems, the questionnaire was revised by a group of professors and members of the infection control committee of the hospital who confirmed the validity of its content.

The questionnaire consisted of three parts. The first part was designed to obtain personal information on the HCWs, such as job category, gender, education, and department. The second part sought to gather information on factors associated with sharp injuries in the past year. The third part focused on the reporting rate of sharp injuries. The completed questionnaires were entered into Epi Info ${ }^{\mathrm{rm}}$ and analyzed using SPSS version 20.0. The association between independent variables and exposure were evaluated using an independent sample Student $t$ test and chi-square test. Stepwise logistical regression was used to analyze the risk factors. A $P$ value of $<0.05$ was considered statistically significant.

All participants were fully informed regarding the purpose of the study, and informed consent was obtained from each participant. The collected data were treated as confidential.

\section{Results}

\section{Characteristics of the included HCWs}

Of $1000 \mathrm{HCW}$ s invited to participate in this study, 901 returned completed survey forms. The overall response rate was $90.1 \%$, and included 301 doctors and 600 nurses (227 males and 674 females). Among the participants,
129 (14.3\%) HCWs had worked in the hospital $>20$ years. Some 363 (40.3\%), 341 (37.8\%) and 197 (21.9\%) HCWs had a college, bachelor, or master degree, respectively. More than half of HCWs (57.7\%) had a primary title with professional qualifications. Almost $30 \%$ of HCWs (29.7\%) had an intermediate title, and 113 (12.5\%) held the title of professor. Most of the HCWs were from the department of surgery 371 (41.2\%) and internal medicine 311 (34.5\%). The number of HCWs who often attended training programs was only $388(43.1 \%)$, and 677 (75.1\%) had standard infection prevention knowledge (Table 1).

\section{Factors associated with the occurrence of sharp injuries}

We analyzed the factors associated with the occurrence of sharp injuries using the chi-square test, which showed that factors such as seniority, job category, title, education, department, and training more or less had an effect on the occurrence of sharp injuries $(P<0.05)$. The incidence of sharp injuries among nurses $(31.2 \%)$ was higher than that among doctors (19.9\%). However, there was no statistically significant difference between male and female participants $(P=0.103)$. HCWs who seldom attended training programs

\begin{tabular}{|c|c|c|c|}
\hline Characteristics & & Number & $\begin{array}{l}\text { Constituent } \\
\text { ratio }(\%)\end{array}$ \\
\hline \multirow[t]{2}{*}{ Gender } & Male & 227 & 25.2 \\
\hline & Female & 674 & 74.8 \\
\hline \multirow[t]{3}{*}{ Seniority } & $<5$ years & 393 & 43.6 \\
\hline & $5 \sim 20$ years & 379 & 42.1 \\
\hline & $>20$ years & 129 & 14.3 \\
\hline \multirow[t]{2}{*}{ Job category } & Doctor & 301 & 33.4 \\
\hline & Nurse & 600 & 66.6 \\
\hline \multirow[t]{3}{*}{ Title } & Primary & 520 & 57.7 \\
\hline & Intermediate & 268 & 29.7 \\
\hline & Professor & 113 & 12.5 \\
\hline \multirow[t]{3}{*}{ Education } & College & 363 & 40.3 \\
\hline & Bachelor & 341 & 37.8 \\
\hline & Master & 197 & 21.9 \\
\hline \multirow[t]{7}{*}{ Department } & Surgery Dept. & 371 & 41.2 \\
\hline & Internal medicine & 311 & 34.5 \\
\hline & Obstetrics and Gynecology & 35 & 3.9 \\
\hline & Emergency Dept. & 72 & 8.0 \\
\hline & Infection Dept. & 25 & 2.8 \\
\hline & Operation room & 73 & 8.1 \\
\hline & Sterile supply room & 14 & 1.6 \\
\hline \multirow[t]{2}{*}{ Training programs } & Seldom & 513 & 56.9 \\
\hline & Often & 388 & 43.1 \\
\hline \multirow{2}{*}{$\begin{array}{l}\text { Standard prevention } \\
\text { Knowledge }\end{array}$} & Unknown & 224 & 24.9 \\
\hline & Known & 677 & 75.1 \\
\hline
\end{tabular}


were more prone to sharp injuries $(33.3 \%)$ than those who often attended training programs (19.6\%). A chi-square test between two similar variables showed that the incidence of sharp injuries among HCWs whose seniority was $<5$ years $(34.4 \%)$ was higher than those whose seniority was $>5$ years $(P<0.05)$. Similarly, there were statistically significant differences between the primary title and other titles $(P<0.05)$, and the incidence of sharp injuries among HCWs with a junior college degree $(35.3 \%)$ was statistically higher than those with a bachelor or master degree $(P<0.05)$. In addition, HCWs in obstetrics and gynecology were more likely to have sharp injuries (42.9\%) than HCWs in other departments according to our study $(P<0.05)$ (Table 2$)$.

Using stepwise logistic regression analysis, the occurrence of sharp injuries was included as the dependent variable, while job category, seniority, title, training programs, education, and department were independent variables. We found that seniority and training programs were the risk factors associated with the occurrence of sharp injuries. HCWs whose seniority was $>20$ years were associated with a decrease in risk for the occurrence of sharp injuries. However, HCWs who seldom attended training programs were associated with an increase in risk for the occurrence of sharp injuries (Table 3).

\section{Reporting rate and reasons for underreporting of sharp injuries exposed to blood}

Of the 130 respondents who experienced sharp injuries exposed to blood, only $44 \mathrm{HCWs}(33.9 \%)$ reported their injuries to the concerned body. There was a statistically significant difference between the type of blood exposure and injury level $(P<0.05)$. However, there were no significant differences between gender, job category, activity, and department $(P>0.05)$ (Table 4$)$.

The main reasons for not reporting the sharp injuries were as follows: perception that the extent of the injury was light (30.2\%), having antibodies (27.9\%), and unaware of injury (16.3\%). Other related reasons for not reporting were unfamiliar with the reporting procedures (11.6\%), thinking that the injury was due to improper operation by themselves (7.0\%), and too busy working to report (7.0\%). There was a significant difference in the unreported reasons between doctors and nurses $(P<0.05)$. The main reasons for not reporting in doctors were as follows: thinking that the extent of the injury was light (53.1\%) and having antibodies (21.9\%), while the main reasons for not

Table 2 Single factor analysis of factors associated with the occurrence of sharp injuries $(N=901)$

\begin{tabular}{|c|c|c|c|c|c|c|}
\hline \multirow[t]{2}{*}{ Variables } & & \multirow{2}{*}{$\begin{array}{l}\text { Number } \\
(N=901)\end{array}$} & \multicolumn{2}{|c|}{ Sharp injuries } & \multirow[t]{2}{*}{$x^{2}$} & \multirow{2}{*}{$\begin{array}{l}P \\
\text { value }\end{array}$} \\
\hline & & & Number & Incidence (\%) & & \\
\hline \multirow[t]{2}{*}{ Gender } & Male & 227 & 53 & 23.3 & 2.65 & 0.103 \\
\hline & Female & 674 & 195 & 28.9 & & \\
\hline \multirow[t]{3}{*}{ Seniority } & $<5$ years & 393 & 135 & 34.4 & 17.97 & 0.000 \\
\hline & 5 20 years & 379 & 90 & 23.7 & & \\
\hline & $>20$ years & 129 & 23 & 17.8 & & \\
\hline \multirow[t]{2}{*}{ Job category } & Doctor & 301 & 61 & 19.9 & 11.94 & 0.001 \\
\hline & Nurse & 600 & 187 & 31.2 & & \\
\hline \multirow[t]{3}{*}{ Title } & Primary & 520 & 173 & 33.3 & 21.23 & 0.000 \\
\hline & Intermediate & 268 & 49 & 18.3 & & \\
\hline & Professor & 113 & 26 & 23.0 & & \\
\hline \multirow[t]{3}{*}{ Education } & Junior college & 363 & 128 & 35.3 & 18.24 & 0.000 \\
\hline & Bachelor & 341 & 76 & 22.3 & & \\
\hline & Master & 197 & 44 & 22.3 & & \\
\hline \multirow[t]{7}{*}{ Department } & Surgery Dept. & 371 & 125 & 33.7 & 25.55 & 0.000 \\
\hline & Internal medicine & 311 & 60 & 19.3 & & \\
\hline & Obstetrics and Gynecology & 35 & 15 & 42.9 & & \\
\hline & Emergency Dept. & 72 & 19 & 26.4 & & \\
\hline & Infection Dept. & 25 & 10 & 40.0 & & \\
\hline & Operation Room & 73 & 15 & 20.5 & & \\
\hline & Sterile supply room & 14 & 4 & 28.6 & & \\
\hline \multirow[t]{2}{*}{ Training programs } & Seldom & 513 & 172 & 33.3 & 21.52 & 0.000 \\
\hline & Often & 388 & 76 & 19.6 & & \\
\hline
\end{tabular}


Table 3 Stepwise logistic regression analysis of factors associated with the occurrence of sharp injuries

\begin{tabular}{lcc}
\hline Variables & OR & $95 \% \mathrm{Cl}$ \\
\hline Seniority & & \\
$\quad<5$ years & & \\
$5 \sim 20$ years & 1.3 & $(0.5,3.3)$ \\
$>20$ years & 0.3 & $(0.1,0.9)$ \\
Training programs & & \\
$\quad$ Often & 1 & $(2.4,12.3)$ \\
$\quad$ Seldom & 5.4 & \\
\hline
\end{tabular}

reporting in nurses were thinking that they had antibodies (31.5\%) and unaware of injury (24.1\%) (Table 5).

\section{Discussion}

Of $1000 \mathrm{HCWs}$ invited to participate in this study, 901 returned completed survey forms, resulting in an overall response rate of $90.1 \%$. The incidence of sharp injuries was $27.5 \%$, which was similar to the incidence reported in other studies [14, 15]. Of 248 sharp injuries, 130 HCWs were exposed to blood. HCWs are vulnerable to accidental exposure to blood and other body fluids while performing clinical activities [16]. Sharp injuries mainly take place during the disposal of used medical waste, and can lead to the transmission of pathogens. At least 20 different pathogens including viruses, bacteria, and fungi can be transmitted to HCWs through sharp injuries. The most common blood-borne diseases are HBV, $\mathrm{HCV}$, and HIV. A national seroepidemiologic survey in 1992 found that the carriage of HBV surface antigen was 9.8\% in China. In our study, HBV surface antigenpositive HCWs accounted for $73.3 \%$, which demonstrates that the prevalence of chronic HBV infection is high in China. However, we observed no seroconversions in $44 \mathrm{HCWs}$ who reported sharp injuries, confirming that the risk of transmission of blood-borne viruses in these events is very low; however, these events should still be a focus of attention.

The present study found that nurses had a significantly higher frequency of occupational sharp injuries than

Table 4 Reporting rate of sharp injuries exposed to blood

\begin{tabular}{|c|c|c|c|c|c|c|}
\hline \multirow[t]{2}{*}{ Variables } & & \multirow[t]{2}{*}{$\begin{array}{l}\text { Number of sharp injuries } \\
\text { exposed to blood }(n=130)\end{array}$} & \multicolumn{2}{|c|}{$\begin{array}{l}\text { Reporting rate of sharp injuries exposed } \\
\text { to blood }\end{array}$} & \multirow[t]{2}{*}{$x^{2}$} & \multirow[t]{2}{*}{$\begin{array}{l}P \\
\text { value }\end{array}$} \\
\hline & & & Reporting number & Reporting rate (\%) & & \\
\hline \multirow[t]{2}{*}{ Gender } & Male & 31 & 12 & 38.7 & 0.43 & $>0.05$ \\
\hline & Female & 99 & 32 & 32.3 & & \\
\hline \multirow[t]{2}{*}{ Job category } & Doctor & 55 & 23 & 41.8 & 2.71 & $>0.05$ \\
\hline & Nurse & 75 & 21 & 28.0 & & \\
\hline \multirow[t]{6}{*}{ Activity } & Disposing used medical waste & 8 & 4 & 50.0 & 8.30 & $>0.05$ \\
\hline & During operation & 23 & 11 & 47.8 & & \\
\hline & Blood drawing & 21 & 9 & 42.9 & & \\
\hline & During medical examination & 16 & 6 & 37.5 & & \\
\hline & Destroyed sharps items & 19 & 6 & 31.6 & & \\
\hline & Withdrawing the needle & 43 & 8 & 18.6 & & \\
\hline \multirow[t]{5}{*}{ Department } & Surgery Dept. & 67 & 22 & $32.8^{* *}$ & $20.29 \%$ & $<0.01$ \\
\hline & Internal medicine & 35 & 9 & $25.7^{* *}$ & & \\
\hline & Emergency Dept. & 6 & 4 & $4 / 6$ & & \\
\hline & Infection Dept. & 7 & 7 & $7 / 7$ & & \\
\hline & Pediatrics & 15 & 2 & $13.3^{* * \Delta}$ & & \\
\hline \multirow[t]{3}{*}{ Type of blood exposure } & HBV & 45 & 33 & $73.3^{\# \#}$ & $65.40^{*}$ & $<0.01$ \\
\hline & $\mathrm{HCV}$ & 5 & $5^{\diamond}$ & $5 / 5^{\# \#}$ & & \\
\hline & Unknown & 80 & 6 & 7.5 & & \\
\hline \multirow[t]{3}{*}{ Injury level } & Light & 52 & 10 & 19.2 & $12.60 \%$ & $<0.01$ \\
\hline & Medium & 75 & 31 & 41.3 & & \\
\hline & Heavy & 3 & 3 & $3 / 3$ & & \\
\hline
\end{tabular}

included 1 case of HIV exposure

* For rank sum test and two rank and inspection, compared with infection Dept

${ }^{* *} P<0.01$; Compared with the emergency department

$\Delta P<0.05$; Compared with the unknown exposure

${ }^{\# \#} P<0.01$ 
Table 5 Reasons for underreporting of different job category

\begin{tabular}{|c|c|c|c|c|c|c|c|c|c|}
\hline \multirow{2}{*}{$\begin{array}{l}\text { Job } \\
\text { catagory }\end{array}$} & \multirow[t]{2}{*}{$n$} & \multicolumn{6}{|c|}{ Reasons for underreporting } & \multirow[t]{2}{*}{$x^{2}$} & \multirow{2}{*}{$\begin{array}{l}P \\
\text { value }\end{array}$} \\
\hline & & $\begin{array}{l}\text { Perception that } \\
\text { the injury is light }\end{array}$ & $\begin{array}{l}\text { Having } \\
\text { antibodies }\end{array}$ & $\begin{array}{l}\text { Unaware } \\
\text { of injury }\end{array}$ & $\begin{array}{l}\text { Unfamiliar with the } \\
\text { reporting procedures }\end{array}$ & $\begin{array}{l}\text { Improper } \\
\text { operation }\end{array}$ & $\begin{array}{l}\text { Too busy working } \\
\text { to report }\end{array}$ & & \\
\hline Doctor & 32 & $17(53.1)$ & $7(21.9)$ & $1(3.1)$ & $2(6.3)$ & $3(9.4)$ & $2(6.3)$ & 2.73 & $<0.01$ \\
\hline Nurse & 54 & $9(16.7)$ & $17(31.5)$ & $13(24.1)$ & $8(14.8)$ & $3(5.6)$ & $4(7.4)$ & & \\
\hline Total & 86 & $26(30.2)$ & 24 (27.9) & $14(16.3)$ & $10(11.6)$ & $6(7.0)$ & $6(7.0)$ & & \\
\hline
\end{tabular}

doctors. Nurses have more chance of contact with sharp instruments, such as needles, when administering injections to agitated patients and disposing of sharp instruments [17]. Nurses often feel tired due to lack of sleep [18], and have varying degrees of job burnout leading to adverse psychological reactions. Sharp injuries further increase job burnout, which lead to a vicious cycle [19]. Sharp injuries often occur in HCWs whose seniority is of short duration. This may be the result of careless work, unskilled technology, nonstandard operations, and poor understanding of occupational safety [20]. The number of HCWs with a primary title injured by sharp instruments was significantly higher than that with a high title. The study also found that different departments had different incidence rates of sharp injuries. The highest number of sharp injuries occurred in the surgery department, and may be related to the characteristics of this department, such as more invasive operations and time constraints. Furthermore, HCWs who seldom attended training programs were more likely to be injured by sharp instruments. There is growing evidence that many cases of occupational exposure to blood and body fluids through needle-stick and sharps injuries are unreported $[5,21]$.

In our study, the reporting rate of sharp injuries was $33.9 \%$ (44/130), and reporting of these injuries varied significantly in different departments. The department of infectious diseases reported all incidents of sharp injuries. HCWs in this department were frequently in contact with patients with blood-borne infectious diseases, attached great importance to occupational safety, and also paid greater attention to sharp injuries compared with other departments. Different sources of exposure had a different reporting rate. When the source of exposure was HBV, the level of concern in HCWs decreased significantly. This is because China has universal HBV vaccination, and most HCWs had antibodies. When the exposure source was HCV or HIV, which have no effective drugs for prevention or treatment, HCWs paid particular attention and a report was prepared when occupational exposure occurred. When the infection source was unknown, HCWs may take measures themselves without preparing a report. In addition, the reporting rate varied with different degrees of injury. Without sufficient understanding of self-protection,
HCWs considered that minor injuries had a low probability of infection, so they paid little attention to these injuries, especially minor injuries, which was one of the main reasons for the lack of reporting in clinical doctors. Some HCWs believed that occupational infections were unlikely to happen to them, and so paid little attention to reporting them. Some HCWs did not know how to report the injury to the concerned body. This may be due to an incomplete reporting procedure, poor information, insufficient recognition of the damage caused by blood-borne occupational diseases, and inappropriate treatment after reporting. Some HCWs considered that sharp injuries were caused by themselves and were afraid of being criticized, so they refused to report the incident.

Although injuries due to sharp instruments in HCWs are inevitable, evaluations by the United States Centers for Disease Control and Prevention showed that $62-80 \%$ of sharp injuries can be prevented [22]. As $22-52 \%$ of needle-stick injuries are the result of recapping, attempts to reduce the incidence of needle-stick injuries have focused on eliminating such practices [23, 24]. However, many approaches such as recommendations against recapping and increasing the accessibility of disposal containers have failed to reduce the incidence of needlestick injuries [25]. Froom et al. proposed that a lecture stressing the dangers of needle-sticks and recommending the use of the scooping method was effective in reducing the risk of needle-stick injuries in medical students [26]. In this hospital, we carried out several preventive countermeasures, such as equipping HCWs with the necessary personal protective equipment, wearing gloves before contact with a patient's blood and body fluids, a ban on recapping needles after use, eliminating unnecessary injections, using automatically retracting safety syringes, and disposing of sharps into a sharps container immediately after use. Although we issued relevant documents on occupational safety, poor compliance with standard precautions is still a risk factor for sharp injuries. The training program on occupational safety requires strengthening, especially for junior HCWs. An effective training program is essential, as its implementation will decrease the overall rate of sharp injuries $[27,28]$. The most common action taken after sharp injuries are compression, washing the site of injury with water and soap, and taking post-exposure prophylaxis against 
HBV and HIV after injury. After exposure to blood, it is necessary to check immunology markers of HBV, HCV, HIV, and other blood-borne diseases, set up health records and provide a reference for prevention.

\section{Conclusions}

This study attempted to investigate the incidence and reporting behavior of sharp injuries and to identify factors associated with sharp injuries among HCWs in Anhui province, China. Our study provided evidence that sharp injuries in the studied hospital were common and were likely to be underreported. Therefore, an effective reporting system and sufficient education on occupational safety are needed in the relevant institutions. Moreover, it is important to take effective measures to manage sharp injuries among HCWs and provide guidance for prevention.

\section{Abbreviations}

HBV: Hepatitis B virus; HCV: Hepatitis C virus; HCWs: Healthcare workers; HIV: Human immunodeficiency virus

\section{Acknowledgements}

We are grateful to all the departments who gave permission to carry out this survey and all the staff who participated in this survey. We would also like to acknowledge our data collection facilitators and friends who provided comments on the proposal structure and arrangement.

\section{Funding}

There was no institutional funding for this study.

\section{Availability of data and materials}

Data sharing is not applicable to this article as no datasets were generated or analyzed during the current study.

\section{Authors' contributions}

$\mathrm{XL}$ and $\mathrm{ZC}$ conceived and designed the research plan. XZ and BW performed the investigation. JZ analyzed the data and performed the statistical analysis. ZC, JZ, and BW wrote the paper. All authors read and approved the final manuscript.

\section{Ethics approval and consent to participate}

This research was approved by the clinical medical research ethics committee of the hospital and conducted in accordance with the Declaration of Helsinki. Informed consent was obtained from each participant. The collected data were treated as confidential.

\section{Consent for publication}

Not applicable.

\section{Competing interests}

The authors declare that they have no competing interests.

\section{Publisher's Note}

Springer Nature remains neutral with regard to jurisdictional claims in published maps and institutional affiliations.

\section{Author details}

'Department of Infection Control, First Affiliated Hospital of Bengbu Medical College, 287 Changhuai Road, Bengbu 233004, People's Republic of China. ${ }^{2}$ Department of Medical Affairs, First Affiliated Hospital of Bengbu Medical College, 287 Changhuai Road, Bengbu 233004, People's Republic of China.
Received: 3 September 2017 Accepted: 28 December 2017

Published online: 10 January 2018

\section{References}

1. Mashoto KO, Mubyazi GM, Mohamed H, Malebo HM. Self-reported occupational exposure to HIV and factors influencing its management practice: a study of healthcare workers in Tumbi and Dodoma Hospitals, Tanzania. BMC Health Serv Res. 2013;13:276. https://doi.org/10.1186/14726963-13-276.

2. Jacob A, Newson-Smith M, Murphy E, Steiner M, Dick F. Sharps injuries among health care workers in the United Arab Emirates. Occup Med (Lond). 2010;60(5):395-7. https://doi.org/10.1093/occmed/kqq039.

3. Balkhy $\mathrm{HH}$, El Beltagy KE, El-Saed A, Sallah M, Jagger J. Benchmarking of percutaneous injuries at a teaching tertiary care center in Saudi Arabia relative to United States hospitals participating in the exposure prevention information network. Am J Infect Control. 2011;39(7):560-5. https://doi.org/ 10.1016/j.ajic.2010.10.022.

4. Serdar T, Derek L, Unic A, Marijancevic D, Markovic D, Primorac A, et al. Occupational exposures in healthcare workers in University Hospital Dubrava-10 year follow-up study. Cent Eur J Public Health. 2013;21(3):150-4.

5. Pruss-Ustun A, Rapiti E, Hutin Y. Estimation of the global burden of disease attributable to contaminated sharps injuries among health-care workers. Am J Ind Med. 2005;48(6):482-90. https://doi.org/10.1002/ajim.20230.

6. Saia MHF, Sharman J, Abiteboul D, Campins M, Burkowitz J, Choe Y, Kavanagh S. Needlestick injuries: incidence and cost in the United States, United Kingdom, Germany, France, Italy, and Spain. Biomed Int. 2010;1(1):41-9.

7. Cullen BL, Genasi F, Symington I, Bagg J, McCreaddie M, Taylor A, et al. Potential for reported needlestick injury prevention among healthcare workers through safety device usage and improvement of guideline adherence: expert panel assessment. J Hosp Infect. 2006;63(4):445-51. https://doi.org/10.1016/j.jhin.2006.04.008.

8. Nagao M, linuma $Y$, Igawa J, Matsumura $Y$, Shirano M, Matsushima A, et al. Accidental exposures to blood and body fluid in the operation room and the issue of underreporting. Am J Infect Control. 2009;37(7):541-4. https:// doi.org/10.1016/j.ajic.2009.01.009.

9. Lakbala P, Sobhani G, Lakbala M, Inaloo KD, Mahmoodi H. Sharps injuries in the operating room. Environ Health Prev Med. 2014;19(5):348-53. https:// doi.org/10.1007/s12199-014-0401-y.

10. Alemayehu T, Worku A, Assefa N. Sharp injury and exposure to blood and body fluids among health care workers in health care centers of eastern Ethiopia. Int J Occup Environ Med. 2016;7(3):172-80.

11. Park S, Jeong I, Huh J, Yoon Y, Lee S, Choi C. Needlestick and sharps injuries in a tertiary hospital in the Republic of Korea. Am J Infect Control. 2008; 36(6):439-43. https://doi.org/10.1016/j.ajic.2007.07.011.

12. Chen $L$, Zhang $M$, Yan $Y$, Miao J, Lin $H$, Zhang $Y$, et al. Sharp object injuries among health care workers in a Chinese province. AAOHN J. 2009:57(1):13-6.

13. Salelkar S, Motghare DD, Kulkarni MS, Vaz FS. Study of needle stick injuries among health care workers at a tertiary care hospital. Indian J Public Health. 2010;54(1):18-20. https://doi.org/10.4103/0019-557X.70540.

14. Lee LK, Hassim IN. Implication of the prevalence of needlestick injuries in a general hospital in Malaysia and its risk in clinical practice. Environ Health Prev Med. 2005;10(1):33-41. https://doi.org/10.1265/ehpm.10.33.

15. Adams S, Stojkovic SG, Leveson SH. Needlestick injuries during surgical procedures: a multidisciplinary online study. Occup Med (Lond). 2010;60(2): 139-44. https://doi.org/10.1093/occmed/kqp175.

16. Talas MS. Occupational exposure to blood and body fluids among Turkish nursing students during clinical practice training: frequency of needlestick/ sharp injuries and hepatitis B immunisation. J Clin Nurs. 2009;18(10):1394403. https://doi.org/10.1111/j.1365-2702.2008.02523.x.

17. Phillips EK, Conaway M, Parker G, Perry J, Jagger J. Issues in understanding the impact of the needlestick safety and prevention act on hospital sharps injuries. Infect Control Hosp Epidemiol. 2013;34(9):935-9. https://doi.org/10.1086/671733.

18. Mehta A, Rodrigues C, Singhal T, Lopes N, D'Souza N, Sathe K, et al. Interventions to reduce needle stick injuries at a tertiary care centre. Indian J Med Microbiol. 2010;28(1):17-20. https://doi.org/10.4103/0255-0857.58722.

19. Wang S, Yao L, Li S, Liu Y, Wang H, Sun Y. Sharps injuries and job burnout: a cross-sectional study among nurses in China. Nurs Health Sci. 2012;14(3): 332-8. https://doi.org/10.1111/j.1442-2018.2012.00697x.

20. Gander P, Purnell H, Garden A, Woodward A. Work patterns and fatiguerelated risk among junior doctors. Occup Environ Med. 2007;64(11):733-8. https://doi.org/10.1136/oem.2006.030916. 
21. Khader Y, Burgan S, Amarin Z. Self-reported needle-stick injuries among dentists in north Jordan. East Mediterr Health J. 2009;15(1):185-9.

22. Worthington K. You've been stuck. What do you do? Am J Nurs. 2001; 101(3):104.

23. McGeer A, Simor AE, Low DE. Epidemiology of needlestick injuries in house officers. J Infect Dis. 1990;162(4):961-4.

24. Whitby M, Stead P, Najman JM. Needlestick injury: impact of a recapping device and an associated education program. Infect Control Hosp Epidemiol. 1991;12(4):220-5.

25. Anderson DC, Blower AL, Packer JM, Ganguli LA. Preventing needlestick injuries. BMJ. 1991;302(6779):769-70

26. Froom P, Kristal-Boneh E, Melamed S, Shalom A, Ribak J. Prevention of needle-stick injury by the scooping-resheathing method. Am J Ind Med. 1998;34(1):15-9.

27. Yang $\mathrm{YH}$, Liou $\mathrm{SH}$, Chen $\mathrm{CJ}$, Yang $\mathrm{CY}$, Wang $\mathrm{CL}$, Chen $\mathrm{CY}$, et al. The effectiveness of a training program on reducing needlestick injuries/sharp object injuries among soon graduate vocational nursing school students in southern Taiwan. J Occup Health. 2007:49(5):424-9.

28. Brusaferro S, Calligaris L, Farneti F, Gubian F, Londero C, Baldo V.

Educational programmes and sharps injuries in health care workers. Occup Med (Lond). 2009;59(7):512-4. https://doi.org/10.1093/occmed/kqp112.

\section{Submit your next manuscript to BioMed Central} and we will help you at every step:

- We accept pre-submission inquiries

- Our selector tool helps you to find the most relevant journal

- We provide round the clock customer support

- Convenient online submission

- Thorough peer review

- Inclusion in PubMed and all major indexing services

- Maximum visibility for your research

Submit your manuscript at www.biomedcentral.com/submit 